\title{
THE EVALUATION OF THE USE OF MOBILE APPS BY CITIZENS OF POLISH VOIVODESHIPS CITIES
}

\begin{abstract}
Summary
Digital government is universally gaining acceptance as the public becomes more technologically advanced. It is critical for the government to embrace new technology for not only minimizing costs and maximizing utility of services to the taxpayers but also for serving the general needs of inhabitants and tourists. The paper focuses on one of the aspect of cities' communication with environment - apps created for mobile phones (smartphones). In past few years there has been a tremendous increase of mobile apps for all major mobile platforms. The objective of the paper is the analysis of mobile apps created by Polish voivodeship cities for Android platform with the use of specially elaborated methodology of evaluating mobile apps.
\end{abstract}

Keywords: m-marketing, mobile apps, self-government, voivodeship cities

\section{Introduction}

Over the last decade, the adoption and utilization of the mobile Internet (MI), i.e., Internet access through cellular communication networks via various portable appliance categories, has surged significantly. The number of worldwide MIenabled users passed the one billion mark in $2011 .^{2}$

To effectively use the mobile internet one needs a mobile device with connection to the internet. According to TNS report "Marketing mobilny w Polsce

\footnotetext{
${ }^{1}$ leszek.gracz@wzieu.pl.

${ }^{2}$ T.J. Gerpott, S. Thomas, Empirical research on mobile Internet usage: A meta-analysis of the literature, "Telecommunications Policy" 2014, No. 38, p. 291.
} 
2013/2014" at the beginning of $201444 \%$ of Poles poses a smartphone. ${ }^{3}$ The same report predicts that in $201560 \%$ of Poles will be owners of smartphones. Among that number at least half of the users will use smartphone apps.

Although smartphone apps already represent an important part of mobile marketing strategies, these apps have received little academic attention within the communication and marketing literature. The objective of the paper is the analysis of the use of smartphone apps by Polish voivodeship cities while targeting two major groups: inhabitants and tourists.

\section{M-marketing and mobile phone application (apps) - literature overview}

As information technology continues to evolve, mobile phones get smarter and smarter. Technological advancements have enabled mobile devices to add more advanced computing ability and broader data connectivity by wireless services, such as $\mathrm{Wi}-\mathrm{Fi}, 3 \mathrm{G}$, and $4 \mathrm{G}$, and have led the advent of current so-called "smartphones". ${ }^{4}$ According to Verkasalo et al. "Smartphones are the devices that can perform dual function i.e. mobile telephone and handheld computer". In particular, $3 \mathrm{G}$ represents the third generation of wireless service, providing higher data speeds, always-on data access, and greater voice capacity ${ }^{6}$. More recently $4 \mathrm{G}$ based on the LTE (long term evolution) system is an upgraded successor of the $3 \mathrm{G}$ standards that is also rapidly growing in Poland. This mobile ultra broadband Internet access is considered one of the features that distinguish smartphones from previous feature phones. ${ }^{7}$ The main differences between smartphones and Internet-enabled computer are presented in table 1.

The development of the smartphones caused the development of mobile marketing. Shankar and Balasubramanian define mobile marketing (m-marketing) as "the two- or multi-way communication and promotion of an offer between a firm and its customers using a mobile medium, device, or technology". ${ }^{8}$

\footnotetext{
${ }^{3}$ Już 44\% Polaków posiada smartfony. I prawie wszyscy odróżniamy je od zwykłego telefonu (infografika), www.tnsglobal.pl/informacje/juz-44-polakow-posiada-smartfony-i-prawie-wszyscyodrozniamy-je-od-zwyklego-telefonu-infografika/ (12.03.2015).

${ }^{4}$ C. Middleton: Delivering services over next generation broadband networks: Exploring devices, applications and networks, "Telecommunications Journal of Australia" 2010, Vol. 60, p. 1-3.

${ }^{5}$ H. Verkasalo, C. López-Nicolás, F.J Molina-Castillo, H. Bouwman, Analysis of users and nonusers of smartphone applications, "Telematics and Informatics" 2010, Vol. 27, Iss. 3, p. 242-255.

${ }^{6} \mathrm{~S}$. Okazaki, P. Barwise, Has the time finally come for the medium of the future?: Research on mobile advertising, "Journal of Advertising Research" 2011, Vol. 51, p. 59-71.

${ }^{7}$ S.Ch. Kim, D. Yoon, E. Han, Antecedents of mobile app usage among smartphone users, "Journal of Marketing Communications" 2014, August, p. 72.

${ }^{8}$ V. Shankar, S. Balasubramanian, Mobile marketing: A synthesis and prognosis, "Journal of Interactive Marketing” 2009, Vol. 23, p. 118.
} 
Table 1

Differences between a smartphone and an internet-enabled computer

\begin{tabular}{|l|l|}
\hline \multicolumn{1}{|c|}{ Internet enabled computer } & \multicolumn{1}{c|}{ Smartphone } \\
\hline Multiple users, family, people in an office & Used typically by only one person \\
\hline $\begin{array}{l}\text { Typically a fixed location. More difficult to } \\
\text { carry and use. Lower battery life (limits } \\
\text { portability) }\end{array}$ & $\begin{array}{l}\text { Fully mobile (not place or network depen- } \\
\text { dent). Longlasting battery enhances porta- } \\
\text { bility }\end{array}$ \\
\hline $\begin{array}{l}\text { Will only be switched on or accessed when } \\
\text { needed. Tethered to a specific, place-de- } \\
\text { pendent network }\end{array}$ & $\begin{array}{l}\text { Owners have the smartphone with them for } \\
\text { most of their waking hours; the phone is al- } \\
\text { ways on with access to a ubiquitous net- } \\
\text { work, typically irrespective of place }\end{array}$ \\
\hline $\begin{array}{l}\text { Owner initiates use. Requires learning mul- } \\
\text { tiple programs and interfaces. Use is more } \\
\text { complex, takes longer (e.g. booting the PC, } \\
\text { followed by initiating the program) and less } \\
\text { intuitive than the smartphone. More diffi- } \\
\text { cult to configure }\end{array}$ & $\begin{array}{l}\text { The owner and those who wish to contact } \\
\text { terfaces, highly-sensitive touch interface, } \\
\text { single Application programming interface } \\
\text { (API)). Easily configurable (home screens, } \\
\text { preferences). Requires little sophistication }\end{array}$ \\
\hline $\begin{array}{l}\text { Multimedia device } \\
\text { Network provider does not know where that } \\
\text { person is geographically }\end{array}$ & $\begin{array}{l}\text { Multimedia device on the go with advanced, } \\
\text { intuitive MM capabilities }\end{array}$ \\
\hline $\begin{array}{l}\text { GPS component, but limited portability. } \\
\text { person is geographically }\end{array}$ & $\begin{array}{l}\text { Device can pinpoint exact location of owner } \\
\text { via GPS component }\end{array}$ \\
\hline $\begin{array}{l}\text { Some may have accelerometer component } \\
\text { built in, but applications are limited (e.g. bi- } \\
\text { cycling) }\end{array}$ & $\begin{array}{l}\text { Accelerometer and gyroscope, portability } \\
\text { means more potential applications and uses }\end{array}$ \\
\hline $\begin{array}{l}\text { Applications are available for download. } \\
\text { Limited catalogue, fewer Independent Soft- } \\
\text { ware Vendors (ISVs), more expensive (very } \\
\text { few are free).applications, typically no } \\
\text { free', less-functional versions available }\end{array}$ & $\begin{array}{l}\text { Many more applications are available for } \\
\text { nical characteristics of device. More ISVs, } \\
\text { lower cost of app (most are free) }\end{array}$ \\
\hline
\end{tabular}

Source: L.F. Pitt, M. Parent, I. Junglas, A. Chan, S. Spyropoulou, Integrating the smartphone into a sound environmental information systems strategy: principles, practices and a research agenda, "Journal of Strategic Information Systems" 2011, Vol. 20, Iss. 1, p. 27-37.

Mobile phones are handheld devices used in accessing, sending and sharing data via call, text and other mechanisms depending on phone features. Mobile phones with Internet capability support similar features and functions as Internetconnected personal computers, laptops and similar computing devices. As such, m-marketing takes advantage of both the mobility and wide reach afforded by mobile technology. ${ }^{9}$ A key driver of the success of m-marketing is the acceptance

\footnotetext{
${ }^{9}$ E.W.T. Ngai, A. Gunasekaran, A review for mobile commerce research and applications, "Decision Support Systems" 2007, Vol. 43, p. 62-76.
} 
and use by consumers since the power of mobile marketing depends on the extent of consumer responsiveness. ${ }^{10}$

A unique characteristic of smartphones is their ability to download and run tens of thousands of applications (apps), which vary from informative to entertaining. Mobile phone applications (apps) are specific m-marketing tools designed for the interchange of information, networking, and leisure. ${ }^{11}$ Taylor et al., defines mobile apps as small programs that run on a mobile device and perform tasks ranging from banking to gaming and web browsing. ${ }^{12}$

The growing popularity of mobile apps is explained by the rise in smartphone ownership. Because mobile apps are an integral part of the smartphone experience, the growing base of smartphone users leads to more apps being developed to serve a wider and wider range of consumer needs. From a marketing perspective, this growth of smartphone ownership and mobile app consumption may create new mobile marketing opportunities beyond the traditional mobile marketing strategies (e.g. SMS advertising). ${ }^{13}$

Mobile apps present value to users in following key areas: ${ }^{14}$

- mobility - the user can conduct business anytime and anywhere,

- flexibility - users can engage in other activities such as travelling while conducting business or transactions,

- ease of use,

- speed with which information can be accessed as a well-made app can provide a far better user experience than even the best websites,

- convenience, as the device tends to be within arms-length of the user for long periods of time,

- security as they provide safe storage of personal data so that users can save time,

- apps provide entertainment or stress release via games apps,

- apps assist users' time management (e.g. reminder calendar scheduling),

\footnotetext{
${ }^{10} \mathrm{~K}$. Heinonen, T. Strandvik, Consumer responsiveness to mobile marketing, "International Journal of Mobile Communications" 2007, Vol. 5, Iss. 6, p. 603.

${ }^{11} \mathrm{Ch}$. Kuan-Yu, H. Yu-Lun, Mobile phone applications as innovative marketing tools for hotels, "The International Journal of Organizational Innovation" 2012, Vol 5, No. 2, Fall, p. 116.

${ }^{12}$ D.G. Taylor, T.A. Voelker, I. Pentina, Mobile application adoption by young adults: A social network perspective, "International Journal of Mobile Marketing" 2011, Vol. 6, No. 2, p. 60-70

${ }^{13}$ S.Ch. Kim, D. Yoon, E. Han, Antecedents of mobile app usage ..., p. 72.

${ }^{14} \mathrm{~J}$. Bredican, D. Vigar-Ellis, Smartphone applications - idea sourcing and app development: implications for firms, "South African Journal of Economic and Management Sciences" 2014, Vol. 17, No. 3, p. 235.
} 
- apps can assist with navigation and trip planning via maps and local information,

- apps can also provide offline access to content or perform functions without a network/wireless connection.

The use of internet communication by self-government units - literature overview

E-administration, that is electronic public administration, has growing influence over society's life quality and growth of its numerous units. Its implementation allows for, among others, the increase in efficiency and decrease in administrative costs. Local governments enter numerous interactions with their environment. The fundamental factor which determines the creation of information society in Poland is common, quick and relatively inexpensive access to services of information society, including the internet resources. The authorities are to provide citizens with their accessibility, confidentiality, reliability and quality of service. ${ }^{15}$

\section{Methodology of the research}

The research was conducted as a pilot test for complex study on the use of mobile apps by self government. The pilot test, out of three main (dominating) mobile operating systems: Android, iOS and Widows Phone focused on Android as the operating system with the largest market share in Poland (and in the world).

The limitation of current study is focus on one mobile platform and one (however dominating) app store. As this study is a pilot test it will be significantly extended during the full study to all platforms and stores.

The data was collected on April 2015, by searching the Google Play store with the phrases of the names of voivodeship cities in Poland. The research results were then analyzed by following aspects:

- the number of total results occurring after searching by a city name,

- the number of apps dedicated to this particular city (there are many apps that are nationwide or worldwide and are not a part of the work of local or regional self-government or local community),

\footnotetext{
${ }^{15}$ A. Smalec, E-administration as a mean of communication between government bodies and their environment, in: Marketing przyszłości. Trendy. Strategie. Instrumenty. Orientacja marketingowa jednostek samorzadu terytorialnego i instytucji publicznych, ed. A. Smalec, Zeszyty Naukowe Uniwersytetu Szczecińskiego No. 775, Problemy Zarządzania, Finansów i Marketingu No. 30, Wyd. Naukowe Uniwersytetu Szczecińskiego, Szczecin 2013, p. 405.
} 
- the number of apps created by (or ordered by) the particular city or region,

- the type of app created by (or ordered by) the particular city (if applicable),

- the evaluation in Google Play store of app created by (or ordered by) the particular city (if applicable).

A great challenge proved to be the identification whether a particular app is in fact prepared or ordered by local or regional self government. The identification was performed by carefully analyzing the apps. Only those apps that had the affirmation of local authorities were considered as created by (or ordered by) the particular city (or region). It is however possible that some app concerning for instance local events were somehow supported by self-government but no indication of that was included in description of the app. In that case the app was not included in the study.

The type of app was determined by the Google Android store category. The cities that are subject of research are the cities that are the place of residence of the voivodeship governor (Polish: wojewoda) and/or a place of voivodeship parliament. According to the current administrative division of Poland ${ }^{16}$, these are the cities of: Wrocław, Bydgoszcz, Torun, Lublin, Gorzów Wielkopolski, Zielona Góra, Łódź, Kraków, Warszawa, Opole, Rzeszów, Białystok, Gdańsk, Katowice, Kielce, Olsztyn, Poznań, Szczecin.

The research was conducted using Google Chrome Version 43.0.2357.124 $\mathrm{m}$, with the use of incognito mode to prevent any possible disruptions in searching. However, as the search engine of Google may differ according to previous user actions as well as geographical region, there may be some results that are missing.

\section{Research results}

The first basic results, presenting the number of search results after the search phrase, applications dedicated to the city or region and application classified as created/ordered by self-government are presented in table 2 .

The high result of search result of the phrase with the name of the city is the effect of many application of national and global scale. Some of these apps, like for instance "mobilet", which is the app for purchasing tickets for public transport occurred in most cities. Such apps are widely used by inhabitants and tourists, yet

\footnotetext{
${ }^{16}$ Act of 24th July 1998 on implementation of basic tree level division of the state, Polish Journal of Laws, No. 96, item 603 with further changes.
} 
they are not dedicated to one city or region. As the subject of the research was finding apps especially dedicated to the particular cities, out of the search results local and regional apps were chosen. The narrowing of the search results to the apps dedicated to each city resulted in smaller number. These apps also differ, ranging from huge, widely used apps such as "Wrocław - przewodnik miejski" (the city of Wrockaw tour guide), with 1115 comments and more than 10.000 downloads to the small, niche apps such as "Kiedy Śmieci Wrocław Fabryczna" (When the trash truck in the region of Wrocław), with one comment and less than 100 downloads.

Table 2

The research results with cities' name phrase in Google Play store

\begin{tabular}{|l|c|c|c|}
\hline \multicolumn{1}{|c|}{ City/search phrase } & $\begin{array}{c}\text { Total number of } \\
\text { search results }\end{array}$ & $\begin{array}{c}\text { Apps dedicated } \\
\text { to the city }\end{array}$ & $\begin{array}{c}\text { Apps created/ordered } \\
\text { by self government }\end{array}$ \\
\hline Wrocław & 256 & 34 & 5 \\
\hline Bydgoszcz & 59 & 9 & 4 \\
\hline Toruń & 220 & 8 & 5 \\
\hline Lublin & 142 & 25 & 1 \\
\hline Gorzów Wielkopolski & 16 & 3 & 1 \\
\hline Zielona Góra & 167 & 6 & 1 \\
\hline Łódź & 248 & 16 & 3 \\
\hline Kraków & 245 & 68 & 3 \\
\hline Warszawa & 256 & 103 & 2 \\
\hline Opole & 40 & 7 & 2 \\
\hline Rzeszów & 63 & 22 & 4 \\
\hline Białystok & 67 & 18 & 5 \\
\hline Gdańsk & 213 & 43 & 2 \\
\hline Katowice & 212 & 22 & 3 \\
\hline Kielce & 40 & 8 & 4 \\
\hline Olsztyn & 54 & 20 & 2 \\
\hline Poznań & 248 & 32 & 28 \\
\hline Szczecin & 204 & & 2 \\
\hline
\end{tabular}

Source: own research.

Out of the apps dedicated to cities the apps created by/ordered by local or regional self government were chosen. Each of the research cities had at least one such app and the highest number was five. It means that the local authorities are aware of the mobile marketing and they undertake actions in this area.

The comprehension of the apps created by/ordered by local or regional self government is presented in table 3 . 
Table 3

The comprehension of the apps created by / ordered by local or regional self government

\begin{tabular}{|c|c|c|c|c|}
\hline The city & Name of the app & Category & $\begin{array}{l}\text { Number of } \\
\text { comments }\end{array}$ & $\begin{array}{l}\text { Mean evaluation } \\
\text { (1 - very bed, } \\
5 \text { - very good) }\end{array}$ \\
\hline \multirow[t]{5}{*}{ Wrocław } & $\begin{array}{l}\text { Wrocław przewodnik } \\
\text { miejski }\end{array}$ & travel \& local & 1115 & 4.3 \\
\hline & Zoo Wrocław mapa & travel \& local & 138 & 4.2 \\
\hline & iMPK & transport & 378 & 3.8 \\
\hline & Wrocław 2016 & travel \& local & 7 & 5.0 \\
\hline & Invest in Wroclaw Region & business & 6 & 3.8 \\
\hline \multirow[t]{4}{*}{ Bydgoszcz } & Bydgoszcz & travel \& local & 50 & 3.8 \\
\hline & $\begin{array}{l}\text { BRA Bydgoski Rower } \\
\text { Aglomeracyjny }\end{array}$ & transport & 58 & 3.8 \\
\hline & Bydgoszcz-wydarzenia & travel \& local & 0 & 0.0 \\
\hline & Parki Krajobrazowe & travel \& local & 20 & 3.7 \\
\hline Toruń & Toruń & travel \& local & 417 & 4.4 \\
\hline \multirow[t]{5}{*}{ Lublin } & Smart Lublin & travel \& local & 43 & 3.9 \\
\hline & Obywatelski Lublin & travel \& local & 21 & 4.1 \\
\hline & Puls Nocy Kultury & skill app & 5 & 4.6 \\
\hline & $\begin{array}{l}\text { Lubelskie Stacje Pogo- } \\
\text { dowe }\end{array}$ & weather & 16 & 5.0 \\
\hline & $\begin{array}{l}\text { Szlak Renesansu Lubel- } \\
\text { skiego }\end{array}$ & travel \& local & 3 & 5.0 \\
\hline $\begin{array}{l}\text { Gorzów } \\
\text { Wielkopolski }\end{array}$ & Bezpieczne Lubuskie & travel \& local & 27 & 4.7 \\
\hline Zielona Góra & Zielona Góra MZK Live & transport & 37 & 3.4 \\
\hline Łódź & Łódź Insider & travel \& local & 158 & 3.2 \\
\hline \multirow[t]{3}{*}{ Kraków } & $\begin{array}{l}\text { Kraków zawsze pod ręką - } \\
\text { MyKRK }\end{array}$ & travel \& local & 146 & 3.9 \\
\hline & Graj Hejnał & leisure & 109 & 3.7 \\
\hline & $\begin{array}{l}\text { Jura Krakowsko Często- } \\
\text { chowska }\end{array}$ & travel \& local & 8 & 4.2 \\
\hline \multirow[t]{3}{*}{ Warszawa } & Archimapa & education & 26 & 4.8 \\
\hline & $\begin{array}{l}\text { Warsaw Uprising Remem- } \\
\text { bered }\end{array}$ & travel \& local & 5 & 5.0 \\
\hline & Pamięć Miasta & travel \& local & 149 & 4.0 \\
\hline Opole & e-wojewoda & tools & 2 & 5.0 \\
\hline \multirow[t]{2}{*}{ Rzeszów } & SegregujRES & social network & 10 & 4.6 \\
\hline & Magiczne Bieszczady & travel \& local & 23 & 3.7 \\
\hline \multirow[t]{2}{*}{ Białystok } & $\begin{array}{l}\text { Białystok - Miejsca z Hi- } \\
\text { storią }\end{array}$ & travel \& local & 33 & 3.8 \\
\hline & $\begin{array}{l}\text { Halfway Festival Biały- } \\
\text { stok }\end{array}$ & $\begin{array}{l}\text { music and so- } \\
\text { und }\end{array}$ & 4 & 4.5 \\
\hline \multirow[t]{4}{*}{ Gdańsk } & gdansk4u MOBILE & travel \& local & 142 & 4.0 \\
\hline & Gdynia City Guide & travel \& local & 122 & 4.4 \\
\hline & $\begin{array}{l}\text { Gdynia i Północne Ka- } \\
\text { szuby }\end{array}$ & travel \& local & 57 & 4.4 \\
\hline & Akcja - Segregacja & education & 4 & 4.0 \\
\hline \multirow[t]{3}{*}{ Katowice } & Katowice 1 - Nikiszowiec & multimedia & 1 & 5.0 \\
\hline & Śląska Policja & travel \& local & 16 & 4.9 \\
\hline & Katowice $2-$ Sródmieście & multimedia & 2 & 5.0 \\
\hline
\end{tabular}




\begin{tabular}{|l|l|c|c|c|}
\hline \multirow{5}{*}{} & $\begin{array}{l}\text { Katowice 3 Śródmieście - } \\
\text { Północ }\end{array}$ & multimedia & 1 & 5 \\
\cline { 2 - 5 } & Park Śląski & travel \& local & 253 & 4.2 \\
\hline \multirow{3}{*}{ Kielce } & Geopark & travel \& local & 19 & 4.9 \\
\cline { 2 - 5 } & Muzeum Wsi Kieleckiej & travel \& local & 9 & 5.0 \\
\hline \multirow{5}{*}{ Poznań } & Bezpieczny Olsztyn & travel \& local & 73 & 4.5 \\
\cline { 2 - 5 } & Visit Olsztyn & travel \& local & 21 & 4.2 \\
\cline { 2 - 5 } & Bezpiecznie nad wodą & medicine & 31 & 4.7 \\
\hline \multirow{3}{*}{ Szczecin } & Poznań Airport Guide & travel \& local & 75 & 4.1 \\
\cline { 2 - 5 } & Przewodnik po Poznaniu & travel \& local & 54 & 3.6 \\
\cline { 2 - 5 } & Visit Szczecin & travel \& local & 143 & 4.1 \\
\cline { 2 - 5 } & Sail Szczecin & travel \& local & 25 & 3.6 \\
\cline { 2 - 5 } & Szczecińskie Cmentarze & travel \& local & 83 & 4.1 \\
\cline { 2 - 4 } & Alert Szczecin & lifestyle & 63 & \\
\hline
\end{tabular}

Source: own research.

Among the apps created by/ordered by local or regional self government dominate the travel and local category - 32 apps out of 54 are within this category. These are mainly the apps created for visiting the city, presenting tourists attractions and some basic information about the city.

There are also more sophisticated apps, like multimedia tour in Katowice, education, leisure, business, lifestyle, etc. Some apps are meant to make life easier for inhabitants, like "Szczecińskie Cmentarze", which is an app that works like a GPS navigation on the "Cmentarz Centralny" (The central graveyard), which is the second biggest cemetery in Europe. Another example can be "Bezpiecznie nad wodą" (Safe by the water) app, which is dedicated to everybody who spends time at the water (lakes, beaches, etc.). The app provides in a quick and simple way the information about how to provide first aid, what are the rules of conduct in emergency situations and where to find the necessary assistance in case of an accident.

A special attention should be paid on apps that are meant to be a real two way communication of the city with inhabitants. Apps such as "Alert Szczecin" are dedicated to support communication by allowing the users to quickly and easily send their opinion on anything that is happening in the city. It is a system for reporting of irregularities in the functioning of the city. In a simple and intuitive way, without any additional formalities, every user of the app can send the feedback to the authorities of the city in areas such as:

- infrastructure (e.g. potholed roads, street lighting),

- cleanliness and order (e.g. a illegal trash dumps),

- security (e.g. no proper marking on dangerous street crossings, illuminate dangerous places), 
- public services (e.g. garbage disposal, dirt),

- public transportation.

There is also a typical app for relations with investors, namely Wrocław's "Invest in Wroclaw Region" app. The app features are:

- information about Wrocław's Shareholders and Partners,

- a fast overview of available plots, warehouses and office spaces on the map,

- a brief description and some pictures of selected offers,

- driving directions from current location to selected item (with Google Maps),

- possibility of sharing the description of given offer using email, Facebook or LinkedIn,

- easy contact with the agencies and institutions providing information about Wroclaw agglomeration business opportunities.

What should also be noticed, the apps elaborated by local authorities receive relatively positive feedback from the users. In the scale offered by Google Play " 5 " is the biggest grade while " 1 " is the lowest. No research application had the grade lower then 3,2 and more than half of them received the grade more then 4 .

\section{Conclusions}

The following conclusions can be drawn from the conducted research:

1. The local and regional authorities in Poland are aware of the m-marketing and importance of mobile apps as a new, interactive channel of reaching the audience.

2. Each voivodeship city in Poland created or contributed to at least one application.

3. The applications of Polish voivodeship cities are mostly city guides with more or less interactivity; however there are some examples of more sophisticated use of the mobile apps.

4. The apps of Polish voivodeship cities are relatively highly valued by their users.

The following recommendations for the future actions can be drawn:

1. The apps in the category "travel and local" are widely used and their constant development should continue; however the full potential of apps for self government should be utilized. Therefore there is a need for more apps dedicated to the true, two way communication with the environment. There are still 
many fields on which mobile apps may prove effective and useful, as indicated in some chosen examples within the paper.

2. Even though the apps are relatively highly evaluated by internet users, they should be continuously improved to reach a greater score, preferably more than 4,5 .

\section{Bibliography}

Act of 24th July 1998 on implementation of basic tree level division of the state, Polish Journal of Laws, No. 96, item 603 with further changes.

Bredican J., Vigar-Ellis D., Smartphone applications - idea sourcing and app development: implications for firms, "South African Journal of Economic and Management Sciences"2014, Vol. 17, No. 3.

Gerpott T.J., Thomas S., Empirical research on mobile Internet usage: A meta-analysis of the literature, "Telecommunications Policy" 2014, No. 38.

Heinonen K., Strandvik T., Consumer responsiveness to mobile marketing, "International Journal of Mobile Communications" 2007, Vol. 5, Iss. 6.

Już 44\% Polaków posiada smartfony. I prawie wszyscy odróżniamy je od zwyklego telefonu (infografika), www.tnsglobal.pl/informacje/juz-44-polakow-posiada-smartfonyi-prawie-wszyscy-odrozniamy-je-od-zwyklego-telefonu-infografika/.

Kim S.Ch., Yoon D., Han E., Antecedents of mobile app usage among smartphone users, "Journal of Marketing Communications" 2014, August.

Kuan-Yu Ch., Yu-Lun H., Mobile phone applications as innovative marketing tools for hotels, "The International Journal of Organizational Innovation" 2012, Vol 5, No. 2, Fall.

Middleton C., Delivering services over next generation broadband networks: Exploring devices, applications and networks, "Telecommunications Journal of Australia" 2010, Vol. 60.

Ngai E.W.T., Gunasekaran A., A review for mobile commerce research and applications, "Decision Support Systems" 2007, Vol. 43.

Okazaki S., Barwise P., Has the time finally come for the medium of the future?: Research on mobile advertising, "Journal of Advertising Research" 2011, Vol. 51.

Pitt L.F., Parent M., Junglas I., Chan A., Spyropoulou S., Integrating the smartphone into a sound environmental information systems strategy: principles, practices and a research agenda. "Journal of Strategic Information Systems" 2011, Vol. 20, Iss. 1.

Shankar V., Balasubramanian S., Mobile marketing: A synthesis and prognosis, "Journal of Interactive Marketing" 2009, Vol. 23.

Smalec A., E-administration as a mean of communication between government bodies and their environment, in: Marketing przyszłości. Trendy. Strategie. Instrumenty. Orientacja marketingowa jednostek samorzadu terytorialnego i instytucji publicznych, ed. A Smalec, Zeszyty Naukowe Uniwersytetu Szczecińskiego No. 775, Problemy Zarządzania, Finansów i Marketingu No. 30, Wyd. Naukowe Uniwersytetu Szczecińskiego, Szczecin 2013.

Taylor D.G., Voelker T.A., Pentina I., Mobile application adoption by young adults: A social network perspective, "International Journal of Mobile Marketing" 2011, Vol. 6, No. 2. 
146

Verkasalo H., López-Nicolás C., Molina-Castillo F.J., Bouwman H., Analysis of users and non-users of smartphone applications, "Telematics and Informatics" 2010, Vol. 27, Iss. 3 .

\section{OCENA WYKORZYSTANIA APLIKACJI MOBILNYCH PRZEZ MIESZKAŃCÓW POLSKICH MIAST WOJEWÓDZKICH}

\section{Streszczenie}

Wraz ze wzrostem zaawansowania technologicznego ludności na znaczeniu zyskuje elektroniczna komunikacja urzędów z otoczeniem. Istotnym aspektem funkcjonowania urzędu jest stosowanie nowych technologii nie tylko w celu minimalizowania kosztów i maksymalizacji użyteczności usług publicznych, ale również do zaspokajania innych potrzeb mieszkańców i turystów. $\mathrm{W}$ artykule skupiono się na wybranym aspekcie komunikacji miast $\mathrm{z}$ otoczeniem, czyli - aplikacjach mobilnych stworzonych dla telefonów komórkowych (smartfonów). W ostatnich kilku latach nastapił dynamiczny wzrost liczby aplikacji mobilnych dla wszystkich platform mobilnych. Celem artykułu jest analiza aplikacji mobilnych stworzonych przez polskie miasta wojewódzkie na platformę Android z użyciem specjalnie przygotowanej do tego celu metodologii badawczej.

Słowa kluczowe: m-marketing, aplikacje mobilne, samorząd lokalny, miasta wojewódzkie

Ttumaczenie: Leszek Gracz 